\title{
News and Comment
}

\section{Yorke Edwards, 1924-2011}

Yorke Edwards died 16 August 2011 in retirement in British Columbia. For nearly 50 years, Yorke was a major contributor to studies of wildlife biology, nature education, and conservation. In 1950, he obtained his Master's degree in zoology at the University of British Columbia with Ian McTaggart Cowan as supervisor. He joined the British Columbia Forest Service in 1951 as a research officer and in 1959 championed nature interpretation in provincial parks. In 1967 he joined the Canadian Wildlife Service and in 1972 joined the British Columbia Provincial Museum as Assistant Director and subsequently was Director from 1975 to 1984 . He was elected an Honorary Member of the Ottawa Field-Naturalists' Club in 1980 in recognition of his contributions to parks and wildlife interpretation.

\section{The Canadian Herpetologist (TCH) 2(2), Fall 2012}

The Canadian Herpetologist (TCH) is a publication produced twice each year by the Canadian Association of Herpetologists and the Canadian Amphibian and Reptile Conservation Network.

CONTENTS: Executive Members of Societies Instructions for Authors - Editorial Notes - Meetings - Feature Articles: Northern Alligator Lizard Lezard-alligator Boreal (Elgaria coerulea principis) by P. Rutherford; Common Five-lined Skink - Scinque pentaligne (Plestiodon fasciatus) by C. Seburn and B. Howes - Field Notes: Sharp-tailed Snake Discovery by L. Anthony; Automated Audio Monitoring of Introduced American Bullfrogs in the Okanagan by N. Lukey, M. Baxter and S. Ashpole - Reviews - Thesis Abstracts in Canadian Herpetology: Boyle, K. M.Sc.
2012. University of Victoria, Victoria, British Columbia. (Supervisor: Pat Gregory). Life in a Drawdown Zone: Natural history, reproductive phenology, and habitat use of amphibians and reptiles in a disturbed habitat. — Perez, A. M.Sc. 2012. Université de Montréal, Montréal, PQ. (Supervisors: Marc J. Mazerolle and Jacques Brisson). Le roseau commun (Phragmites australis) influence-til la composition spécifique et le développement larvaire d'amphibiens? - Riley, J. M.Sc. 2012. Laurentian University, Sudbury, Ontario. (Supervisor: Jacqueline Litzgus). The Importance of Nest Environment for Turtle Conservation, Hatchling Overwintering Strategy, and Fitness. - Recent Publications in Canadian Herpetology — News and Announcements — Membership Forms: CARCNET.

\section{Erratum The Canadian Field-Naturalist 126(3): 245}

The title of the article should be: Gray, David R., and Sally E. Gray. 2012. A tribute to Stewart Dixon MacDonald, 1927-2010. Canadian Field-Naturalist 126(3): 245-251. 